\title{
Organ Sparing Approach in Bilateral Testis Tumors: A Short Review of the Literature with a Featuring Case
}

\author{
(1) Volkan DEMIRCAN, ${ }^{1}$ (D) Müge AKMANSU, 2 (D) Serhat ÇETIN, ${ }^{3}$ (1) Sinan SÖZEN³ \\ 'Department of Radiation Oncology, University of Health Sciences, Şanlıurfa Mehmet Akif İnan Training and Research Hospital, \\ Şanlıurfa-Turkey \\ 2Department of Radiation Oncology, Gazi University Faculty of Medicine, Ankara-Turkey \\ ${ }^{3}$ Department of Urology, Gazi University Faculty of Medicine, Ankara-Turkey
}

\section{Dear Editor,}

Testicular cancer (TC) is very rare in clinical practice. It represents only $1-2 \%$ of all cancers.[1] However, TC is the most common malignancy in men between 15 and 40 years old.[2] Race, cryptorchidism, genetics, maternal estrogen exposure, and previous TC are main known risk factors.[3,4] Western and Northern Europe populations have significantly high incidence for TC. [5] Pathological classification of TCs consists of germ cell tumors (GCT), stromal tumors, ITGCN, and others. More than $90 \%$ of TC has GCT histology.[6] GCT is divided into 2 main subgroups such as seminomas and non-seminomatous tumors. Non-seminomatous GCT has 5 subtypes such as embryonal carcinoma, yolk sac tumors, choriocarcinoma, teratoma, and mixed tumors. Our patient has mixed GCT histology. Average age of presentation of mixed GCT is 30 years old.[7] Any combination of histological subtypes is formally possible, although admixture of embryonal carcinoma and teratoma is more frequent. [8]

Our patient was 24 years old. He did not have any other comorbidity. He has noticed swelling in his scrotum and was timely administered to hospital. A $3.5 \mathrm{~cm}$ solid mass was reported in his left testicle with USG. Serum $\beta$-Hcg, AFP, and LDH levels were $437 \mathrm{mIU} /$ $\mathrm{ml}, 903 \mathrm{ng} / \mathrm{mL}, 362 \mathrm{IU} / \mathrm{L}$, respectively. Left inguinal orchiectomy was performed to the patient in August 2011. There was no complication after surgery. Admixture of yolk sac and teratoma were reported by pathologists. Serum $\beta$-Hcg, AFP and LDH levels decreased to $25.7 \mathrm{mIU} / \mathrm{ml}, 289 \mathrm{ng} / \mathrm{mL}, 179 \mathrm{IU} / \mathrm{L}$, respectively, in the $1^{\text {st }}$ post-operative week. Regression of tumor markers was continued within $1 \frac{1 / 2}{2}$ months after the surgery. They were at completely normal levels by the $6^{\text {th }}$ postoperative week. Systemic evaluation was made with thoracic and abdominopelvic CT scan. There was no sign of metastasis in the body. Although serum tumor marker levels decreased to normal values, the normalization time was longer than expected. Two cycles of BEP (cisplatin $100 \mathrm{mg} / \mathrm{m}^{2}$, etoposid $150 \mathrm{mg} / \mathrm{m}^{2}$, and bleomycin $30 \mathrm{U}$ ) were given to the patient in October 2011. Then, the patient followed up with testing of tumor marker levels in every 3 months and radiologic imaging in every 4 months. While the patient was screening with stable disease, prominent progression of tumor marker levels was detected in routine laboratory tests in December 2013. Serum $\beta$-Hcg, AFP levels were $173.5 \mathrm{mIU} / \mathrm{ml}$ and $36 \mathrm{ng} / \mathrm{mL}$, respectively. Scrotal USG showed $1.5 \mathrm{~cm}$ mass at the inferior pole of the right testicle. Right testis sparing surgery (TSS) was performed immediately after USG result. During surgery, 2 punch biopsies were taken from normal testis parenchyma. Pathology report revealed a mixed GCT with a combination of embryonal carcinoma (65\%), yolk sac (20\%), teratoma (10\%), and choriocarcinoma (5\%). Lymphovascular invasion was seen. Surgical margins were intact. Furthermore, ITGCN reported in the residual testis parenchyma. Therefore, 20 Gy radiotherapy (RT) (Figs. 1, 2) was given to residual testis in 10 fractions in January 2014. Serum $\beta$-Hcg, AFP levels were 3600 $\mathrm{mIU} / \mathrm{ml}$ and $255 \mathrm{ng} / \mathrm{mL}$, respectively, in the $1^{\text {st }}$ post-operative week. Serum $\beta$-Hcg, AFP levels were 2400 mIU/ 


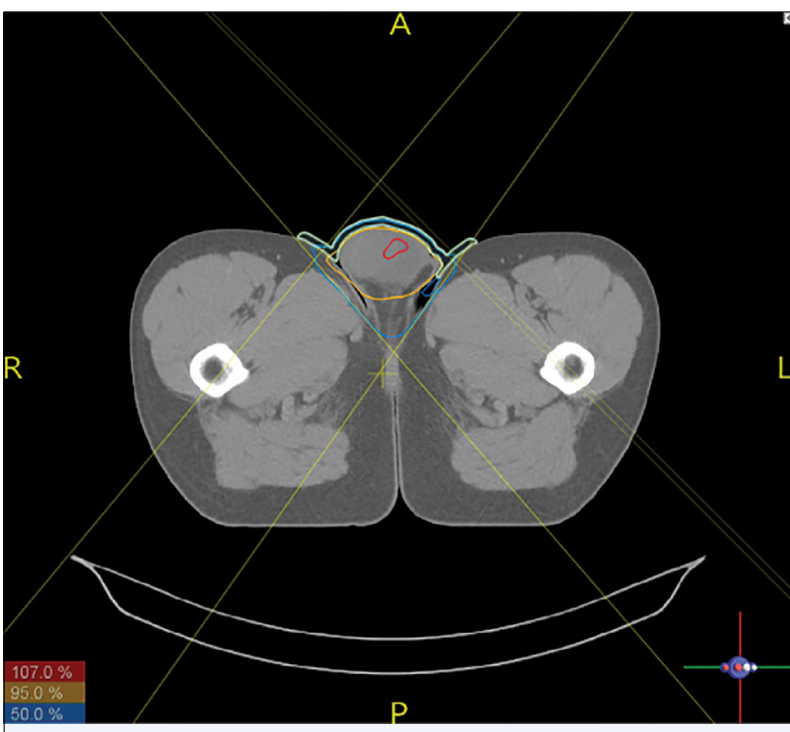

Fig. 1. Coronal view of the radiotherapy (RT) plan. Isodose lines red, yellow, and blue represent $107 \%$, $95 \%$, and $50 \%$ of the total dose, respectively. IGRT (image-guided radiotherapy) is used to minimize setup errors and interfraction differences. A bolus was placed superficially to the skin to maintain an adequate surface dose.

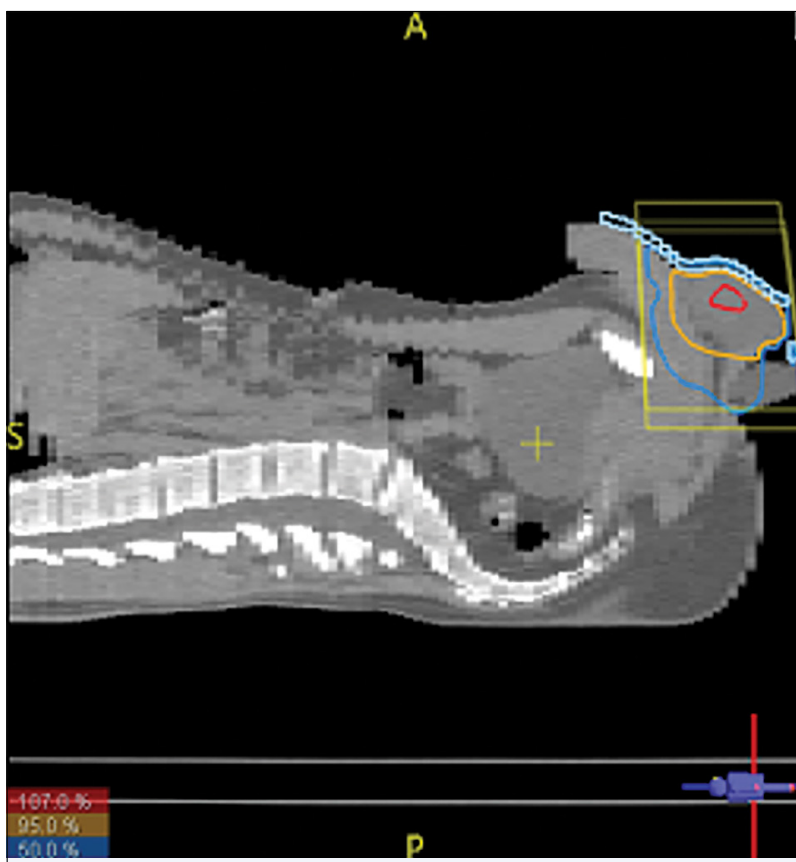

Fig. 2. Sagittal view of the radiotherapy (RT) plan. Isodose lines red, yellow, and blue represent 107\%, $95 \%$, and $50 \%$ of the total dose, respectively. The penis retracted superiorly to avoid from RT field. The $95 \%$ isodose line covers all of the remaining testis volumes. $\mathrm{ml}$ and $180 \mathrm{ng} / \mathrm{mL}$, respectively, after the RT. PET scan showed increased FDG uptake at the distal paraaortic lymph node (SUVmax 7.3). Consequently, the patient was referred to medical oncology for systemic therapy. Afterward, 4 cycles of EP chemotherapy were applied to the patient. EP chemotherapy was completed in March 2014. Serum $\beta-\mathrm{Hcg}$, AFP levels were $1.6 \mathrm{mIU} / \mathrm{ml}$ and $7.8 \mathrm{ng} / \mathrm{mL}$, respectively, after EP chemotherapy. Regression of involved lymph node and decreased uptake of FDG (SUVmax 2.6) were reported in control PET scan in May 2014. During follow-up, 3 consecutive measurements of serum $\beta-\mathrm{Hcg}$ levels were seen progressively increased in June $2014(64 \rightarrow 122 \rightarrow 223 \mathrm{mIU} / \mathrm{ml})$. Accordingly, 3 cycles of TIP chemotherapy were planned. TIP (paclitaxel $250 \mathrm{mg} / \mathrm{m}^{2}$, ifosfamide $1.5 \mathrm{~g} / \mathrm{m}^{2}$, mesna $1.5 \mathrm{mg} / \mathrm{m}^{2}$, and cisplatin $25 \mathrm{mg} / \mathrm{m}^{2}$ ) chemotherapy was completed in August 2014. Serum tumor marker levels were totally normal in September 2014. There is still no evidence of disease (NED). Survival is 110 months and disease-free survival is 74 months now. There is no long-term complication of treatment except testosterone deficiency due to the Leydig cells destruction.

Radical orchiectomy is the gold standard treatment for TC. However, TSS may be alternative to radical orchiectomy, especially in bilateral tumors to prevent testosterone deficiency. Although there are several publications about TSS in the literature, there is no scientific consensus on this topic. The common idea is being cautious for assigning patients to TSS. [9,10] EAU guidelines recommend the use of TSS to patients, which have solitary testis, for preserving infertility and hormonal function, which is compatible with our patient.[11]

ITGCN is a precursor lesion of cancer. Heidenreich et al. stated that ITGCN is seen at the residual testis parenchyma in $82 \%$ of 73 patients after TSS in their study. Existence of ITGCN ends up with TC in $50-80 \%$ of cases. [12,13] Therefore, RT is required in case of ITGCN. Although RT is effective for controlling the disease, it damages Leydig cells and causes testosterone deficiency at the same time. In this regard, determination of RT dose is very crucial. Leydig cells are very sensitive to radiation. It is showed that doses as low as 6 Gy can affect Leydig cells. [14] On the other hand, according to literature, optimal RT dose for ITGCN is 20 Gy.[15] There are several studies in the literature comparing 20 Gy with lower doses (14-16 Gy) in the aspects of both disease control and hormone profile. However, decreasing the RT dose may lead to an increasing risk of disease relapse. [16-18] Consequently, hypogonadism rates after RT are reported as $25-30 \%$ in the literature.[18,19] In 
compliance with literature findings, we applied $20 \mathrm{~Gy}$ RT. Unfortunately, our patient ended up with testosterone deficiency and required hormone substitution. $\mathrm{He}$ is getting $1000 \mathrm{mg}$ testosterone replacement every 3 months.

Testosterone deficiency is a consequence of both RT and chemotherapy. Recent researches indicated that cisplatin-based regimens cause subclinical hypogonadism by affecting Leydig cells' function. [20,21] Furthermore, another effect of radio and chemotherapy is reported in the literature. Higher serum LH levels are associated with a decrement in testosterone production in the remaining irradiated testicular tissue. Furthermore, platinium-based chemotherapeutics have a cumulative effect on Leydig cells.[22] According to this data, testosterone deficiency was inevitable in this case as a result of intense treatment.

Overall survival (OS) rates for bilateral synchronous TC are lower than metachronous contralateral TC according to SEER database. The 10 -year OS rate for patients diagnosed with metachronous contralateral TC has been reported as 93\% in SEER analysis. [23] However, there are many publications reporting different OS time for bilateral TC patients with different histology, stage, and risk factors in the literature. Klatte et al. reported that all of the patients were alive after a median follow-up of 95 months for 11 metachronous bilateral TC patients. However, only 1 of 11 patients had non-seminomatous mixed GCT histology.[24] Similarly, in the study by Hentrich et al.,[25] 32 of 33 metachronous bilateral TC patients were reported as alive with NED after a median follow-up of 41 months. Furthermore, in the study by MD Anderson Cancer Center for bilateral TC, it has been stated that only 1 of 24 patients died due to the metastatic disease.[26] In parallel with literature findings, our patient survived for 110 months and is still following up with NED.

Our patient evaluated as stage $1 \mathrm{~S}$ at the time of diagnosis, according to serum tumor marker levels (S1). Therefore, despite return of tumor marker levels to normal at 1.5 months after surgery, 2 cycles of BEP were given to the patient according to recommendations from NCCN guidelines. $[27,28]$ At the time of relapse, our patient had stage $2 \mathrm{~A}$ disease because of $\mathrm{N} 1$ lymph node. Serum tumor marker levels were prominently high after TSS. Persistent marker elevation after surgery was a significant independent predictor of recurrence.[29] Four cycles of EP were applied to the patient. After EP chemotherapy, markers turned down to normal levels in March 2014. However, $\beta$-Hcg values elevated on 3 serial measurements in June 2014. Therefore, the patient was accepted again with the relapsed disease and received 3 cycles of TIP chemotherapy as the second-line regimen. TIP regimen is very useful for relapsed GCT. Motzer et al. reported of a complete positive response from 24 out of 30 patients with relapsed GCT who were treated with TIP regimen.[30]

Although CT is the standard modality for detecting abdominal or retroperitoneal lymphadenopathies, its false negative rates have been observed as high as $30-59 \%$ in the literature.[31,32] However, potential of $\mathrm{PET} / \mathrm{CT}$ to improve clinical staging of TCs has reported recently.[33] Besides, prospective studies of the German multicenter PET study group revealed that PET/ $\mathrm{CT}$ is only slightly better than CT as a primary staging tool for stage 1/2 non-seminomatous GCTs.[34] Furthermore, they reported that PET/CT is not better than serum tumor markers and CT for evaluating treatment response after chemotherapy for non-seminomatous GCTs. [35] In light of this information, we performed CT scans for routine radiological follow-up and treatment response evaluation of our patient. In addition, we further combined PET/CT with CT scans for improving the accuracy of clinical staging and treatment response evaluation.

Management of bilateral testis tumors requires a wide consideration of several issues all together, including control of disease, following of serum tumor markers, making decisions on necessity of adjuvant treatments, timing of therapies assigned, applying of proper RT techniques, and controlling of long-term side effects. Our patient has been treated with the multimodality approach under cooperation of different departments. BTCs may have an excellent prognosis. However, close follow-up of the disease and multimodality approach should always be considered. Organ sparing approach can be a useful treatment alternative in selected patients.

\section{References}

1. Bosl GJ, Motzer RJ. Testicular germ-cell cancer. N Engl J Med 1997;337(4):242.

2. Chia VM, Quraishi SM, Devesa SS, Purdue MP, Cook $\mathrm{MB}, \mathrm{McGlynn} \mathrm{KA}$, et al. International trends in the incidence of testicular cancer, 1973-2002. Cancer Epidemiol Biomarkers Prev 2010;19(5):1151-9.

3. Garner MJ, Turner MC, Ghadirian P, Krewski D. Epidemiology of testicular cancer: An overview. Int J Cancer 2005;116(3):331-9. 
4. Shankar S, Davies S, Giller R, Krailo M, Davis M, Gardner $\mathrm{K}$, et al. In utero exposure to female hormones and germ cell tumors in children. Cancer 2006;106(5):1169-77.

5. Park JS, Kim J, Elghiaty A, Ham WS. Recent global trends in testicular cancer incidence and mortality. Medicine (Baltimore) 2018;97(37):e12390.

6. Bahrami A, Ro JY, Ayala AG. An overview of testicular germ cell tumors. Arch Pathol Lab Med 2007;131(8):1267-80.

7. Konstantinos S, Panagiotis P, Georgios P, Galariotis $\mathrm{N}$, Olympitis M, Moschouris $\mathrm{H}$, et al. Mixed germ cell tumor of the testicle with ravdomuosarcomatous component: A case report. Cases J 2009;2:9299.

8. Mostofi FK, Sesterhenn IA. Pathology of germ cell tumors of testes. Prog Clin Biol Res 1985;203:1-34.

9. Keske M, Canda AE, Yalcin S, Kilicarslan A, Kibar Y, Tuygun $\mathrm{C}$, et al. Is testis-sparing surgery safe in small testicular masses? Results of a multicentre study. Can Urol Assoc J 2017;11(3-4):E100-4.

10. Khan MJ, Bedi N, Rahimi MN, Kalsi J. Testis sparing surgery for small testicular masses and frozen section assessment. Cent European J Urol 2018;71(3):304-9.

11. Albers P, Albrecht W, Algaba F, Bokemeyer C, CohnCedermark G, Fizazi K, et al. Guidelines on testicular cancer: 2015 update. Eur Urol 2015;68(6):1054-68.

12. Hoei-Hansen CE, Rajpert-De Meyts E, Daugaard G, Skakkebaek NE. Carcinoma in situ testis, the progenitor of testicular germ cell tumours: A clinical review. Ann Oncol 2005;16(6):863-8.

13. Heidenreich A, Weissbach L, Holtl W, Albers P, Kliesch S, Köhrmann KU, et al. Organ sparing surgery for malignant germ cell tumor of the testis. J Urol 2001;166(6):2161-5.

14. Sivakumar R, Sivaraman PB, Mohan-Babu N, JainulAbideen MI, Kalliyappan P, Balasubramanian K. Radiation exposure impairs luteinizing hormone signal transduction and steroidogenesis in cultured human leydig cells. Toxicol Sci 2006;91(2):550-6.

15. Krege S, Beyer J, Souchon R, Albers P, Albrecht W, Algaba $\mathrm{F}$, et al. European consensus conference on diagnosis and treatment of germ cell cancer: A report of the second meeting of the European germ cell cancer consensus group (EGCCCG): Part I. Eur Urol 2008;53(3):478-96.

16. Petersen PM, Giwercman A, Daugaard G, Rorth M, Petersen JH, Skakkebaek NE, et al. Effect of graded testicular dose of radiotherapy in patients treated for carcinoma-in situ in the testis. J Clin Oncol 2002;20(6):1537-43.

17. Bang AK, Petersen JH, Petersen PM, Andersson AM, Daugaard G, Jørgensen N. Testosterone production is better preserved after 16 than 20 Gray irradiation treatment against testicular carcinoma in situ cells. Int J Radiat Oncol Biol Phys 2009;75(3):672-6.

18. Giwercman A, von der Maase H, Berthelsen JG, Rørth M, Bertelsen A, Skakkebaek NE. Localized irradiation of testes with carcinoma in situ: Effects on Leydig cell function and eradication of malignant germ cells in 20 patients. J Clin Endocrinol Metab 1991;73(3):596-603.

19. Dieckmann KP, Wilken S, Loy V, Matthies C, Kleinschmidt K, Bedke J, et al. Treatment of testicular intraepithelial neoplasia (intratubular germ cell neoplasia unspecified) with local radiotherapy or with platinum-based chemotherapy: A survey of the German testicular cancer study group. Ann Oncol 2013;24(5):1332-7.

20. Hansen SW, Berthelsen JG, von der Maase H. Longterm fertility and Leydig cell function in patients treated for germ cell cancer with cisplatin, vinblastine, and bleomycin versus surveillance. J Clin Oncol 1990;8(10):1695-8.

21. Brennemann W, Stoffel-Wagner B, Helmers A, Mezger J, Jäger N, Klingmüller D.. Gonadal function of patients treated with cisplatin based chemotherapy for germ cell cancer. J Urol 1997;158(3):844-50.

22. Sprauten M, Brydøy M, Haugnes HS, Cvancarova M, Bjøro T, Bjerner J, et al. Longitudinal serum testosterone, luteinizing hormone, and follicle-stimulating hormone levels in a population-based sample of long-term testicular cancer survivors. J Clin Oncol 2014;32(6):571-8.

23. Fossa SD, Chen J, Schonfeld SJ, McGlynn KA, McMaster ML, Gail MH, et al. Risk of contralateral testicular cancer: A population-based study of 29, 515 U.S. men. J Natl Cancer Inst 2005;97(14):1056-66.

24. Klatte T, de Martino M, Arensmeier K, Reiher F, Allhoff EP, Klatte D. Management and outcome of bilateral testicular germ cell tumors: A 25-year single center experience. Int J Urol 2008;15(9):821-6.

25. Hentrich M, Weber N, Bergsdorf T, Liedl B, Hartenstein R, Gerl A. Management and outcome of bilateral testicular germ cell tumors: Twenty-five year experience in Munich. Acta Oncol 2005;44(6):529-36.

26. Che M, Tamboli P, Ro JY, Park DS, Ro JS, Amato RJ, et al. Bilateral testicular germ cell tumors: Twenty-year experience at M. D. Anderson cancer center. Cancer 2002;95(6):1228-33.

27. Lv ZJ, Wu S, Dong P, Yao K, He YY, Gui YT, et al. Clinical outcomes in patients with stage I non-seminomatous germ cell cancer. Asian J Androl 2013;15(4):558-63.

28. Mezvrishvili Z, Managadze L. Three cycles of etoposide and cisplatin chemotherapy in clinical stage IS nonseminomatous testicular cancer. Int Urol Nephrol 
2006;38(3-4):621-4.

29. Rabbani F, Sheinfeld J, Farivar-Mohseni H, Leon A, Rentzepis MJ, Reuter VE, et al. Low-volume nodal metastases detected at retroperitoneal lymphadenectomy for testicular cancer: Pattern and prognostic factors for relapse. J Clin Oncol 2001;19(7):2020-5.

30. Motzer RJ, Sheinfeld J, Mazumdar M, Bains M, Mariani T, Bacik J, et al. Paclitaxel, ifosfamide, and cisplatin second-line therapy for patients with relapsed testicular germ cell cancer. J Clin Oncol 2000;18(12):2413-8.

31. Fernandez EB, Moul JW, Foley JP, Colon E, McLeod DG. Retroperitoneal imaging with third and fourth generation computed axial tomography in clinical stage I nonseminomatous germ cell tumors. Urology 1994;44(4):548-52.

32. McLeod DG, Weiss RB, Stablein DM, Muggia FM, Paulson DF, Ellis JH, et al. Staging relationships and outcome in early stage testicular cancer: A report from the Testicular cancer intergroup study. J Urol 1991;145(6):1178-83.

33. Cremerius U, Wildberger JE, Borchers H, Zimny M, Jakse G, Günther RW, et al. Does positron emission tomography using 18-fluoro-2-deoxyglucose improve clinical staging of testicular cancer?-results of a study in 50 patients. Urology 1999;54(5):900-4.

34. de Wit M, Brenner W, Hartmann M, Kotzerke J, Hellwig D, Lehmann J, et al. [18F]-FDG-PET in clinical stage I/II non-seminomatous germ cell tumours: Results of the German multicentre trial. Ann Oncol 2008;19(9):1619-23.

35. Oechsle K, Hartmann M, Brenner W, Venz S, Weissbach L, Franzius C, et al. [18F] Fluorodeoxyglucose positron emission tomography in nonseminomatous germ cell tumors after chemotherapy: The German multicenter positron emission tomography study group. J Clin Oncol 2008;26(36):5930-5. 